$\begin{array}{rr}\text { FIT(1)PATOLOGI } & \text { Volume 13, Nomor 3, Mei } 2017 \\ \text { IN D ONESIA } & \text { Halaman 98-104 } \\ \text { ISSN: } 0215-7950 & \text { DOI: } 10.14692 / \text { jfi.13.3.98 }\end{array}$

\title{
Deteksi dan Identifikasi Spesies Meloidogyne Penyebab Umbi Berbintil pada Kentang Asal Sulawesi Utara
}

\author{
Detection and Identification of Meloidogyne Species, \\ Pimple-like Knot Pathogen of Potato Tuber From North Sulawesi
}

\author{
Budi Sri Utami, Supramana*, Giyanto \\ Institut Pertanian Bogor, Bogor 16680
}

\begin{abstract}
ABSTRAK
Nematoda puru akar (Meloidogyne spp.) adalah salah satu penyebab menurunnya produksi kentang di Sulawesi Utara. Hingga saat ini spesies Meloidogyne pada kentang di Sulawesi Utara belum diidentifikasi. Penelitian ini bertujuan mendeteksi dan mengidentifikasi spesies Meloidogyne pada kentang dan mengetahui hubungan kekerabatannya dengan spesies dari negara lain. Sampel umbi kentang bergejala bintil dikumpulkan dari 3 sentra produksi kentang di Provinsi Sulawesi Utara, yaitu Kakenturan (Minahasa Selatan), Purworejo, dan Singsingon (Bolaang Mongondow Timur). Identifikasi morfologi dilakukan berdasarkan pola perineal nematoda betina. Identifikasi molekuler dengan teknik PCR menggunakan primer spesifik untuk mengamplifikasi daerah ITS-rDNA, dilanjutkan dengan sikuensing fragmen DNA dan analisis filogenetika. Dua spesies Meloidogyne berhasil diidentifikasi, yaitu M. javanica (sampel asal Kakenturan, Purworejo, Singsingon), dan M. incognita (sampel asal Purworejo). M. javanica dan M. incognita sampel asal Sulawesi Utara memiliki tingkat homologi berturut-turut hingga $97.5 \%$ dan $100 \%$ dengan spesies yang sama asal Cina.
\end{abstract}

Kata kunci: homologi, identifikasi molekuler, ITS-rDNA, morfologi

\begin{abstract}
Root-knot nematode (Meloidogyne spp.). is one of the main constraint of potato production in North Sulawesi. Little is known about Meloidogyne species infecting potatoes in North Sulawesi. Therefore, research was conducted to identify Meloidogyne spp. on potatoes in North Sulawesi and further study their relationship with related species from other countries. Infected potato tubers with pimple-like knot symptom were collected from three potato production centers, i.e. Kakenturan (South Minahasa), Purworejo, and Singsingon (East Bolaang Mongondow). Morphological identification was conducted based on the perineal pattern of the female; whereas molecular identification was conducted by PCR using specific primer for ITS-rDNA, followed by DNA sequencing and phylogenetic analysis. Two Meloidogyne species were identified i.e. M. javanica (samples form Kakenturan, Purworejo and Singsingon) and $M$. incognita (samples from Purworejo). M. javanica and $M$. incognita from North Sulawesi are similar to the related species from China with homology level of $97.5 \%$ and $100 \%$, respectively.
\end{abstract}

Key words: homology, ITS-rDNA, morphology, molecular identification

*Alamat penulis korespondensi: Departemen Proteksi Tanaman, Fakultas Pertanian, Institut Pertanian Bogor. Jalan Kamper, Kampus Darmaga IPB, Bogor 16680.

Tel: 0251-8629364, Faks: 0251-8629362, Surel: supramana@ipb.ac.id 


\section{PENDAHULUAN}

Nematoda puru akar (NPA) atau Meloidogyne spp. merupakan nematoda yang banyak menyerang tanaman kentang. Gejala khas infeksi NPA pada kentang ialah adanya bintil atau puru di permukaan umbi, tanaman menjadi kerdil, layu, dan klorosis (Bacic et al. 2016).

M. incognita, $M$. javanica, $M$. arenaria, $M$. hapla, M. fallax dan M. chitwoodi merupakan nematoda yang merugikan secara ekonomi pada pertanaman kentang (Adam et al. 2007). Tiga spesies Meloidogyne ditemukan menginfeksi pertanaman kentang di Pulau Jawa, yaitu M. javanica, M. incognita dan M. arenaria (Aprilyani et al. 2015). NPA secara morfologi sangat mirip satu dengan lain dan beberapa spesies nematoda puru akar sering ditemukan bersamaan menginfeksi tanaman.

Penyakit umbi berbintil pada kentang merupakan salah satu kendala produksi kentang di Sulawesi Utara. Belum ada informasi mengenai spesies Meloidogyne yang menginfeksi kentang di Sulawesi Utara dan kerugian yang ditimbulkan akibat infeksi nematoda. Deteksi dan identifikasi spesies NPA perlu dilakukan secara morfologi yang didukung oleh teknik molekuler. Metode identifikasi NPA secara molekuler dengan amplifikasi bagian DNA ribosom pada daerah internal transcribed spacer selain lebih cepat juga lebih akurat (Zijlstra et al. 2000).

Penelitian ini bertujuan mendeteksi dan mengidentifikasi spesies Meloidogyne penyebab umbi berbintil kentang di Sulawesi Utara berdasarkan karakter morfologi dan molekuler, serta menentukan kekerabatan spesies Meloidogyne berdasarkan analisis filogenetika.

\section{BAHAN DAN METODE}

\section{Pengambilan Sampel Umbi}

Pengambilan sampel dilakukan di 3 lokasi, yaitu Desa Kakenturan, Kecamatan Modoinding, Kabupaten Minahasa Selatan Kabupaten Minahasa Selatan yang terletak pada ketinggian $1181 \mathrm{~m}$ dpl (S: 047'21.79'
E: 124'28'52.67'); Desa Purworejo, Kecamatan Modayag, Kabupaten Bolaang Mongondow Timur yang terletak pada ketinggian $1144 \mathrm{~m}$ dpl (S: $0^{\circ} 43^{\prime} 31.07^{\prime}$ E: 12426’31.45'); Desa Sinsingon, Kecamatan Pasi Timur, Kabupaten Bolaang Mongondow yang terletak pada ketinggian $1205 \mathrm{~m}$ dpl (S: $0^{\circ} 48^{\prime} 00.27^{\prime}$ E: 124'23'13.99'). Pada setiap wilayah contoh diambil 5 lokasi pertanaman kentang yang berbeda. Pengambilan sampel dilakukan secara purposif, yaitu memilih sampel berdasarkan pada gejala penyakit tanaman yang spesifik. Tanaman kentang sakit bagian tajuknya menguning, kerdil dan layu pada saat siang hari, serta umbinya bergejala puru/bintil.

\section{Identifikasi Spesies Meloidogyne}

Nematoda betina dipisahkan dari jaringan umbi menggunakan jarum preparat dan diletakkan di dalam cawan sirakus yang telah diberi air. Pembuatan preparat pola perineal nematoda betina dilakukan pada 100 nematoda per wilayah pengamatan. Meloidogyne diidentifikasi dengan kunci identifikasi Eisenback dan Triantaphyllou (1991).

Identifikasi spesies Meloidogyne dengan teknik PCR dilakukan dengan mengamplifikasi daerah 18S-28S ITS rDNA nematoda betina, kemudian dilakukan sikuensing. Selanjutnya sikuen yang diperoleh dibandingkan dengan sikuen standar yang terdaftar di GenBank. Ekstraksi DNA nematoda betina menggunakan metode Tesarova et al. (2003) yang telah dimodifikasi dengan menambahkan $\mathrm{NaOAc}$ untuk presipitasi DNA. Amplifikasi DNA dengan teknik PCR menggunakan primer spesifik untuk M. incognita, M. javanica, $M$. arenaria, dan primer multipleks untuk $M$. hapla, M. fallax, dan M. chitwoodi (Tabel 1). Setiap reaksi diperlukan $12.5 \mu \mathrm{L}$ 2x Go Taq ${ }^{\circledR}$ Green Master mix (Promega), $1 \mu \mathrm{L}$ primer forward $10 \mu \mathrm{M}, 1 \mu \mathrm{L}$ primer reverse $10 \mu \mathrm{M}$, $2 \mu \mathrm{L}$ templat DNA, dan $8.5 \mu \mathrm{L}$ air bebas nuklease sehingga volume menjadi $25 \mu \mathrm{L}$.

\section{Perunutan Nukleotida dan Analisis Filogenetika \\ Perunutan susunan nukleotida dilakukan di First Base, Singapura. Hasil}


Tabel 1 Pasangan primer yang digunakan untuk identifikasi spesies Meloidogyne dengan teknik polymerase chain reaction

\begin{tabular}{|c|c|c|c|c|}
\hline Spesies & $\begin{array}{l}\text { Kode } \\
\text { Primer }\end{array}$ & Runutan 5'- 3' & $\begin{array}{l}\text { Target } \\
\text { DNA } \\
(\mathrm{pb})\end{array}$ & $\begin{array}{l}\text { Sumber } \\
\text { Rujukan }\end{array}$ \\
\hline M. incognita & $\begin{array}{l}\text { MI-F } \\
\text { MI-R }\end{array}$ & $\begin{array}{l}\text { GTGAGGATTCAGTCTCCCAG } \\
\text { ACGAGGAACATACTTCTCCGTCC }\end{array}$ & \pm 999 & $\begin{array}{l}\text { Meng et al. } \\
\text { (2004) }\end{array}$ \\
\hline M. arenaria & $\begin{array}{l}\text { Far } \\
\text { Rar }\end{array}$ & $\begin{array}{l}\text { TCGGCGATAGAGGTAAATGAC } \\
\text { TCGGCGATAGACACTACAACT }\end{array}$ & \pm 420 & $\begin{array}{l}\text { Zijlstra et al. } \\
\quad(2000)\end{array}$ \\
\hline M. javanica & $\begin{array}{l}\text { Fjav } \\
\text { Rjav }\end{array}$ & $\begin{array}{l}\text { GGTGCGCGATTGAACTGAGC } \\
\text { CAGGCCCTTCAGTGGAACTATAC }\end{array}$ & \pm 420 & $\begin{array}{l}\text { Zijlstra et al. } \\
\quad(2000)\end{array}$ \\
\hline $\begin{array}{l}\text { M. hapla } \\
\text { M. chitwoodi } \\
\text { M. fallax }\end{array}$ & $\begin{array}{l}\text { JMV1 } \\
\text { JMVhapla } \\
\text { JMV2 }\end{array}$ & $\begin{array}{l}\text { GGATGGCGTGCTTTCAAC } \\
\text { AAAAATCCCCTCGAAAAATCCACC } \\
\text { TTTCCCCTTATGATGTTTACCC }\end{array}$ & $\begin{array}{l} \pm 440 \\
\pm 540 \\
\pm 670\end{array}$ & $\begin{array}{l}\text { Wishart et al. } \\
\text { (2002) }\end{array}$ \\
\hline
\end{tabular}

sikuen dianalisis menggunakan program basic local alignment search tool (BLAST) dengan program optimasi untuk mendapatkan sikuen DNA yang terdapat dalam situs National Center For Biotechnology Information (http:// www.ncbi.nlm.nih.gov/blast/Blast.cgi). Runutan nukleotida kemudian disejajarkan dengan perangkat lunak Clustal W (Larkin et al. 2007) pada program bioedit sequence alignment editor v 7.0.5.3 (Hall 1999). Pohon filogenetika dibentuk dengan piranti lunak molecular evolutionary genetic analysis software (MEGA) 6 (Tamura et al. 2013) dengan boostrap 1000 kali ulangan.

\section{HASIL}

\section{Gejala Infeksi NPA}

Tanaman kentang yang diduga terinfeksi NPA menunjukkan gejala pada bagian tajuk tanaman layu, pertumbuhan tanaman yang terhambatdan kerdil, daunklorosis (Gambar 1). Gejala khas Meloidogyne spp. terlihat pada umbi kentang berupa bintil atau puru pada permukaan, berbintil dan bergelombang, dan permukaan tidak rata bahkan sering disertai dengan adanya infeksi patogen lain sehingga umbi mengalami kerusakan lebih parah (Gambar 2). Bagian umbi yang terinfeksi NPA bila kulit luarnya dikupas akan terlihat adanya titik-titik berwarna putih kekuningan yang merupakan nematoda betina bila dilihat di bawah mikroskop (Gambar 3).

\section{Spesies Meloidogyne}

Berdasarkan pengamatan pola perineal Meloidogyne spp. betina ditemukan 2 spesies, yaitu $M$. javanica dan $M$. incognita. $M$. javanica ditemukan dari semua lokasi pengambilan sampel dengan ciri adanya garis lateral yang memisahkan bagian striae dorsal dan ventral (Gambar 4a). M. incognita hanya ditemukan pada sampel asal Purworejo dengan ciri lengkung dorsal yang tinggi dan menyempit, sedangkan pada bagian paling luarnya sedikit melebar dan agak mendatar, tidak memiliki garis lateral dan bagian striae terlihat jelas (Gambar 4b).

Perunutan asam nukleat hasil amplifikasi daerah ITS rDNA digunakan untuk mengetahui tingkat kekerabatan suatu spesies yang sudah tersimpan pada database GenBank. Fragmen DNA dengan ukuran 720 pb berhasil diamplifikasi dengan primer spesifik M. javanica pada sampel asal Purworejo, Sinsingon, dan Kakenturan (Gambar 5a); sedangkan primer spesifik $M$. incognita berhasil mengamplifikasi fragmen DNA berukuran $999 \mathrm{pb}$ pada sampel asal Purworejo (Gambar 5b).

Runutan nukleotida $M$. javanica dari Purworejo, Kakenturan dan Sinsingon telah disejajarkan dengan $M$. javanica dari negara lain yang tersedia di GenBank. M. javanica asal Purworejo memiliki homologi paling tinggi dengan spesies $M$. javanica dari Cina dan India dengan nilai 97.5\%, M. javanica asal Kakenturan homologi paling tinggi 


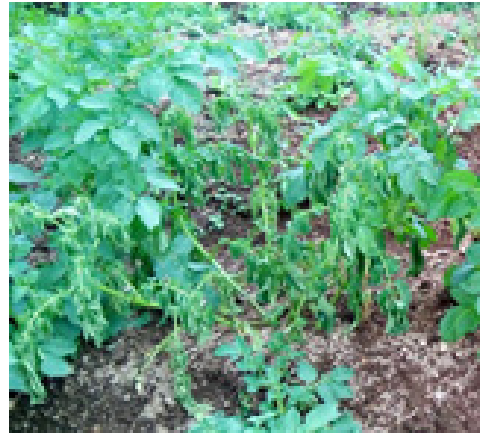

a

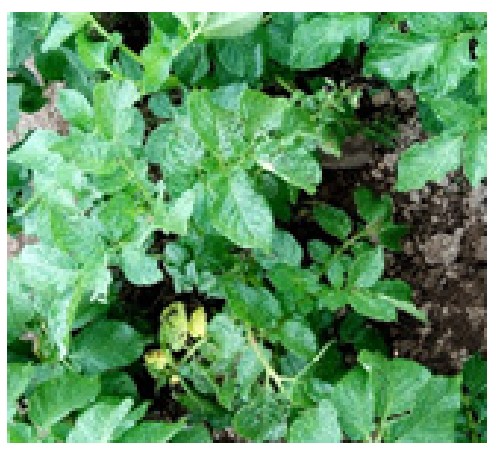

b

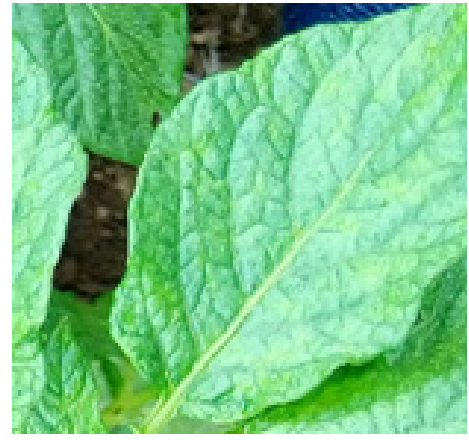

c

Gambar 1 Gejala tanaman kentang terinfeksi Meloidogyne spp. a, Tanaman layu; b, Tanaman kerdil dan; c, Klorosis pada daun.

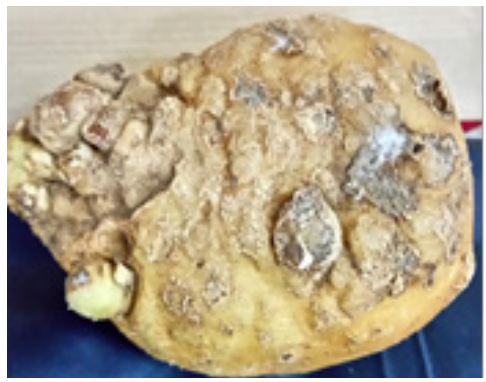

a

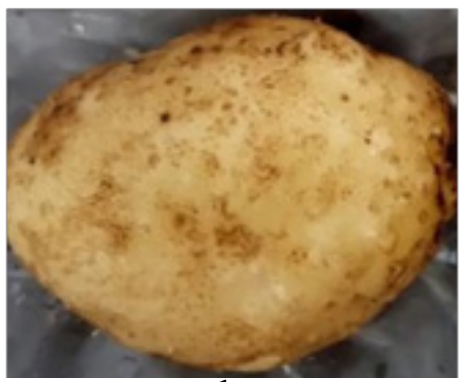

b

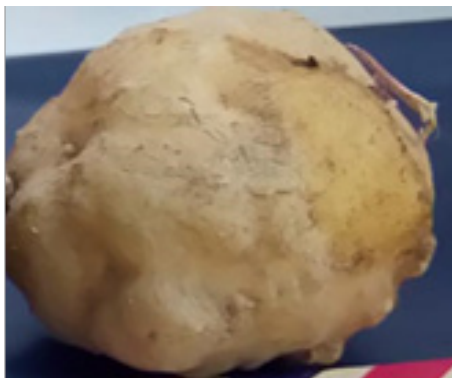

C

Gambar 2 Variasi gejala serangan Meloidogyne spp. pada umbi kentang. a, Malformasi bentuk; b, Bintil kecil dan tidak rata dan; c, Tonjolan dan umbi bergelombang.

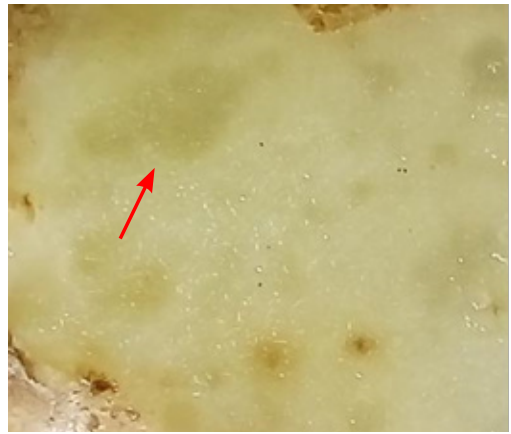

a

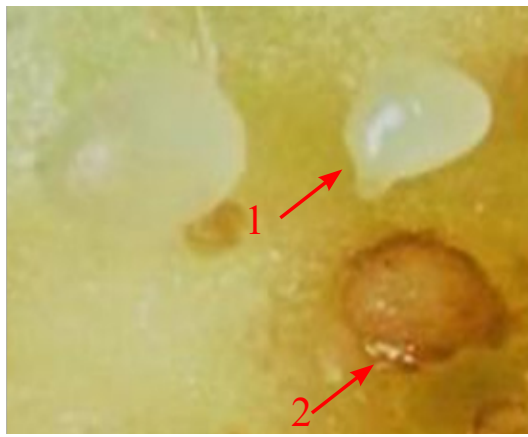

b

Gambar 3 Gejala dan tanda infeksi Meloidogyne spp. a, Nekrosis pada jaringan umbi $(\rightarrow)$; b, Meloidogyne sp (1, betina dewasa; dan 2, massa telur).

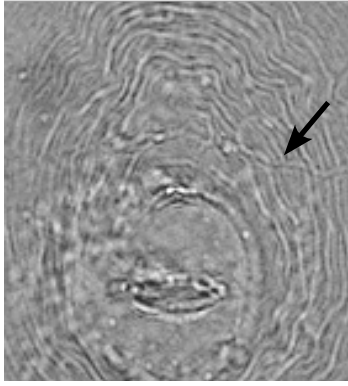

a

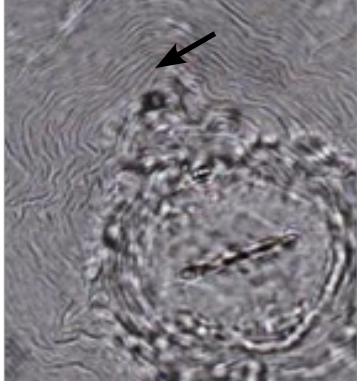

b

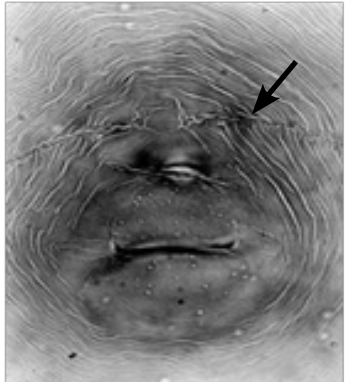

c

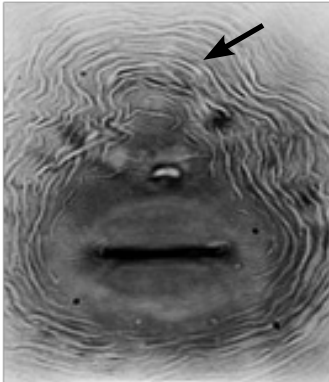

d

Gambar 4 Pola perineal Meloidogyne javanica dan M. incognita asal Purworejo (Perbesaran 400x) (a dan b) dan acuannya (c dan d), yaitu Eisenback et al. (1981). $(\rightarrow$ ) menunjukkan ciri garis lateral yang memisahkan bagian striae dorsal dan ventral (a dan c); ciri lengkung dorsal yang tinggi dan menyempit (b dan d). a dan c, M. javanica; b dan d, M. incognita. 
dengan spesies $M$. javanica dari Cina dan India dengan nilai $91.8 \%$, dan $M$. javanica asal Sinsingon nilai homologi yang paling tinggi dengan isolat $M$. javanica dari Cina yaitu sebesar $91.3 \%$ (Tabel 2). Analisis filogenetika menunjukkan bahwa ketiga isolat $M$. javanica asal Purworejo, Kakenturan, dan Sinsingon memiliki kekerabatan dengan $M$. javanica asal Cina, Thailand, India dan Malaysia (Gambar 6).

Setelah dilakukan penyejajaran dengan isolat $M$. incognita dari negara lain, runutan nukleotida $M$. incognita asal Purworejo memiliki tingkat homologi $100 \%$ dengan $M$. incognita dari Cina. Berdasarkan analisis filogentika $M$. incognita asal Purworejo juga diketahui berkerabat dekat $M$. incognita dari Cina, India, Thailand dan Malaysia (Gambar 7).

\section{PEMBAHASAN}

Dua spesies Meloidogyne, yaitu $M$. javanica dan $M$. incognita, berhasil diidentifikasi secara morfologi. M. javanica

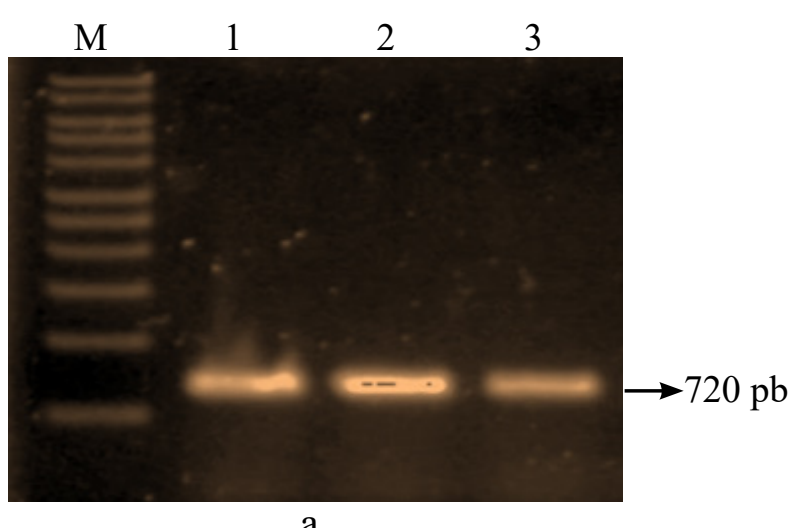

ditemukan pada seluruh lokasi pengambilan sampel, sedangkan $M$. incognita hanya ditemukan pada sampel asal Purworejo. Dropkin (1991) menyatakan bahwa terdapat hubungan antara iklim dan karakter tanah terhadap distribusi Meloidogyne. Suhu optimum untuk perkembangan $M$. incognita ialah $15-25^{\circ} \mathrm{C}$. M. javanica dapat berkembang dan bereproduksi pada suhu optimum sekitar 20-30 ${ }^{\circ} \mathrm{C}$. Keberadaan spesies Meloidogyne spp. di Sulawesi Utara berkaitan erat dengan kondisi iklim, suhu tahunan daerah pengambilan sampel yang berkisar $16-30{ }^{\circ} \mathrm{C}$.

Identifikasi molekuler menggunakan primer SCAR Fjav dan Rjav berhasil mengamplifikasi M. javanica asal Purworejo, Kakenturan dan Sinsingon dengan ukuran pita DNA sekitar $720 \mathrm{pb}$. Zijlstra et al. (2000) menggunakan wilayah ITS rDNA sebagai target PCR untuk mengidentifikasi $M$. arenaria, M. javanica dan M. incognita dengan primer SCAR dengan sampel DNA dari massa telur, juvenil, dan nematoda betina. Primer spesifik MI-F dan MI-R untuk M. incognita

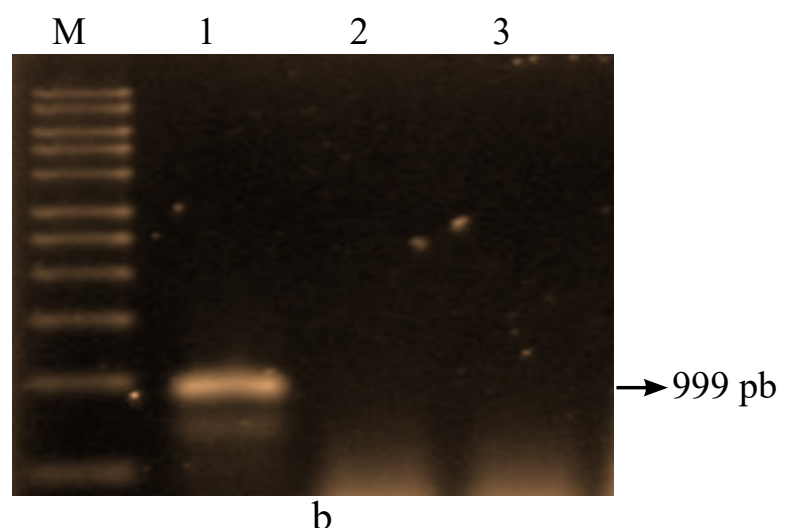

Gambar 5 Hasil amplifikasi DNA spesies Meloidogyne menggunakan primer spesifik. a, Meloidogyne javanica; dan b, Meloidogyne incognita. M, penanda DNA $1 \mathrm{~kb}$ (Biolabs); 1, sampel Purworejo; 2, sampel Kakenturan; 3, sampel Sinsingon.

Tabel 2 Homologi (\%) runutan nukleotida M. javanica asal Sulawesi Utara dengan M. javanica dari beberapa negara lain yang ada di GenBank

\begin{tabular}{lccccc}
\hline & $\begin{array}{c}\text { Meloidogyne javanica } \\
\text { (GenBank) }\end{array}$ & & 3 & $\begin{array}{c}\text { Meloidogyne javanica } \\
\text { asal Sulawesi Utara }\end{array}$ \\
\cline { 1 - 2 } \cline { 5 - 6 } Asal & No. Aksesi & & Purworejo & Kakenturan & Sinsingon \\
\hline India & KP411877.1 & & 97.5 & 91.8 & 92.9 \\
India2 & KP411878.1 & & 97.5 & - & 92.7 \\
Cina & JN005834.1 & & 97.5 & 91.8 & 93.1 \\
Thailand & KF913681.1 & & 97.1 & 91.4 & 92.7 \\
Malaysia & KF041327.1 & & 95.6 & 91.1 & - \\
\hline
\end{tabular}




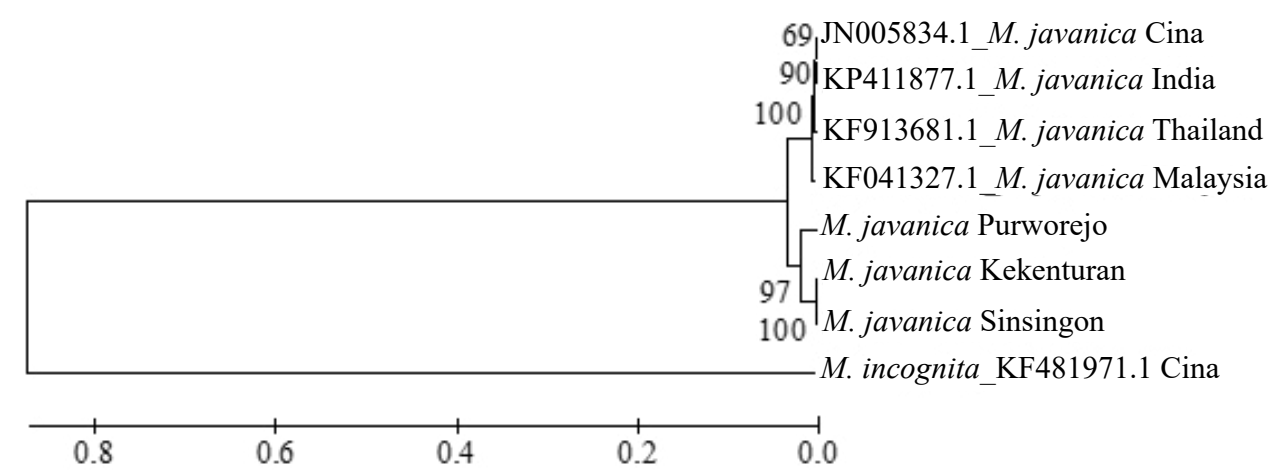

Gambar 6 Pohon filogentika Meloidogyne javanica asal Purworejo, Kakenturan, dan Singsingon dengan $M$. javanica negara lain yang terdapat pada GenBank berdasarkan runutan nukleotida menggunakan program MEGA v 6.06 dengan pendekatan UPGMA. Skala di bawah gambar adalah skala nilai koefisien jarak genetik yang menggambarkan jumlah rata-rata perubahan nukleotida di antara isolat.

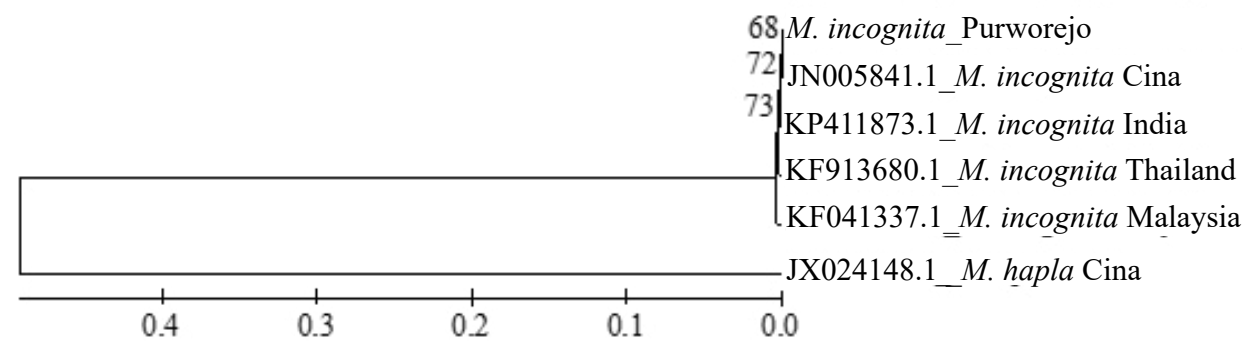

Gambar 7 Pohon filogentika Meloidogyne incognita asal Purworejo dengan M. incognita dari negara lain yang terdapat pada GenBank berdasarkan runutan nukleotida menggunakan program MEGA v 6.06 dengan pendekatan UPGMA. Skala di bawah gambar adalah skala nilai koefisien jarak genetik.

yang dirancang oleh Meng et al. (2004) hanya dapat mengamplifikasi $M$. incognita yang berasal dari Purworejo dengan ukuran pita DNA sekitar $999 \mathrm{pb}$.

Identifikasi molekuler memperkuat hasil identifikasi secara morfologi keberadaan spesies utama NPA, yaitu $M$. javanica dan $M$. incognita penyebab umbi berbintil kentang di Sulawesi Utara. Dua spesies Meloidogyne tersebut juga telah dilaporkan menginfeksi pertanaman kentang di Pulau Jawa (Aprilyani et al. 2015), sedangkan pada tanaman wortel di Pulau Jawa dan Gowa, Sulawesi Selatan telah berhasil diidentifikasi $M$. incognita, $M$. javanica, M. arenaria, dan M. hapla (Taher et al. 2012; Hikmia et al. 2012; Halimah et al. 2013; Mirsam et al. 2015). Berdasarkan hasil wawancara di lokasi pengambilan sampel, bibit kentang yang ditanam di Sulawesi Utara berasal dari Pengalengan, Jawa Barat. Diduga bibit kentang yang berasal dari Jawa Barat tersebut merupakan medium pembawa M. javanica dan M. incognita ke Sulawesi Utara. M. javanica dan $M$. incognita yang menginfeksi kentang merupakan laporan pertama di Sulawesi Utara.

Analisis filogentika $M$. javanica dan $M$. incognita asal Sulawesi Utara berkerabat dekat dengan spesies yang sama asal Cina, Thailand, India, dan Malaysia. Kedekatan kekerabatan antara $M$. javanica dan M. incognita asal Sulawesi Utara dengan $M$. javanica dan $M$. incognita asal Cina menunjukkan kemungkinan adanya faktor pemasukan umbi (kentang dan wortel) dari negara tersebut sebagai penyebab tersebarnya nematoda puru akar ini. Pusdatin (2013) mencatat bahwa Cina termasuk salah satu negara pengekspor benih kentang ke Indonesia.

\section{UCAPAN TERIMA KASIH}

Penulis mengucapkan terima kasih kepada Badan Karantina Pertanian yang telah memberi beasiswa (kepada penulis pertama). Ucapan terima kasih disampaikan kepada Ifa Manzila dan Fitrianingrum Kurniawati atas bantuan dan bimbingannya. 


\section{DAFTAR PUSTAKA}

Adam MAM, Phillips MS, Blok VC. 2007. Molecular diagnostic key for identification of single juveniles of seven common and economically import species of rootknot nematode (Meloidogyne spp.). Plant Pathol. 56:190-197. DOI: https://doi. org/10.1111/j.1365-3059.2006.01455.x.

Bacic J, Stare BG, Strajnar P, Sirca S, Urek G. 2016. First report of a highly damaged potato crop from serbia caused by Meloidogyne incognita. APS Journal 100(5): 1021. DOI: htpp://dx.doi. org/10.1094/PDIS-09-15-1072-PDN.

Aprilyani, Supramana, Suastika G. 2015. Meloidogyne incognita penyebab umbi berbintil pada kentang di beberapa sentra produksi kentang di Jawa. J Fitopatol Indones 11(5): 143-149. DOI: https://doi. org/10.14692/jfi.11.5.143.

Dropkin VH. 1991. Pengantar Nematologi Tumbuhan. Ed ke-2. Supratoyo, editor. Yogyakarta (ID): Gadjah Mada University Press. Terjemahan dari: Introduction to Plant Nematology.

Eisenback JD, Hirschman H, Sasser JN, Triantaphyllou AC. 1981. A Guide to The Four Most Common Spesies of Root-Knot Nematodes (Meloidogyne spp.), With a Pictural Key. Washington DC (US): Cooperative Publication Department of Plant Pathology an US Agency International Development.

Hall TA. 1999. BioEdit: a user-friendly biological sequence alignment editor a analysis program for Windows 95/98/ NT. Nucleic Acids Symposium Series. 41:95-98.

Halimah, Supramana, Suastika G. 2013. Identifikasi spesies Meloidogyne pada wortel berdasarkan sikuen nukleotida. J Fitopatol Indones. 9(1):1-6. DOI: https:// doi.org/10.14692/jfi.9.1.1.

Hikmia Z, Supramana, Suastika G. 2012. Identifikasi spesies Meloidogyne spp. penyebab umbi bercabang pada tanaman wortel di Jawa Timur. J Fitopatol Indones. 8(3):73-78.

Larkin MA, Blackshields, Brown NP, Chenna $\mathrm{R}$, McGettigan PA, Mc William $\mathrm{H}$,
Valentin F, Wallace IM, Wilm A, Lopez R, Thompson JD, Gibson TJ, Higgins DG. 2007. Clustal W and Clustal X version 2.0. Bioinformatic. 23(21):2947-2948. DOI: https://doi.org/10.1093/bioinformatics/ btm404.

Meng QP, Long H, Xu JH. 2004. PCR assay for rapid and sensitive identification of three major root-knot nematodes, Meloidogyne incognita, M. javanica, and M. arenaria. Acta Phytopathol Sinica. 34(3):204-210.

Mirsam H, Supramana, Suastika G. 2015. Deteksi dan identifikasi spesies Meloidogyne pada tanaman wortel dari Dataran Tinggi Malino, Gowa, Sulawesi Selatan. J Fitopatol Indones 11(1): 1-8. DOI: https://doi.org/10.14692/jfi.11.1.1.

[Pusdatin] Pusat Data dan Sistem Informasi Pertanian. 2013. Kentang. Buletin Konsumsi Pangan 4(1):15-24.

Taher M, Supramana, Gede S. 2012. Identifikasi Meloidogyne penyebab penyakit umbi bercabang pada wortel di Dataran Tinggi Dieng. J Fitopatol Indones. 8(1):16-21. DOI: https://doi.org/10.14692/jfi.8.1.16.

Tamura K, Stecher G, Peterson D, Filipski A, Kumar S. 2013. MEGA6 : Molecular evolutionary genetics analysis version 6.0. Mol Biol Evol. 30(12):2725-2729. DOI: https://doi.org/10.1093/molbev/mst197.

Tesarova B, Zouhar M, Rysanek P. 2003. Development of PCR for specific determination of root-knot nematode Meloidogyne incognita. Plant Protect. 39(1):23-28.

Wishart J, Philips MS, Bblok VC. 2002. Ribosomal intergenic spacer: a polymerase chain reaction diagnostic for Meloidogyne chitwoodi, M. fallax, and M. hapla. Phytopatology 92 (8): 884-892. DOI: https://doi.org/10.1094/ PHYTO.2002.92.8.884.

Zijlstra C, Dorine TH, Donkers-Venne M, Fargette M. 2000. Identification of Meloidogyne incognita, M. javanica, and $M$. arenaria using sequence characterised amplified region (SCAR) based PCR assay. Nematology. 2(8):847-853. DOI: https:// doi.org/10.1163/156854100750112798. 